\section{INTERPERSONAL DIALOGUE TO BUILD STUDENTS' ABILITY IN USING ENGLISH}

\author{
Nurul Hidayati \\ English Study Program, Sekolah Tinggi Bahasa Asing Pontianak \\ nurulalvaro.na@gmail.com
}

Interpersonal

Dialogue, ELT, Ability, Using English

\begin{abstract}
This study aims to saw the implementation of interpersonal dialogue in learning English to enhance students' ability in using the English language. This study used a qualitative method. The data collection technique used observation techniques to saw the process of the implementation of learning to uses interpersonal dialogue, and interview techniques to determine the impact of implementing interpersonal dialogue. Respondents in this study were lecturers and students. The results showed that during the learning process, the interpersonal dialogue was created between students and students and the lecturer. Then, there is an increase in learning activities, student participation, students get additional knowledge in the form of vocabulary, grammar, pronunciation, and self-confidence. In conclusion, the implementation of interpersonal dialogue can build communicative learning, because of the interactive communication between students and lecturers, as well as students and students during the learning process. As well as increasing student ability and student confidence in using English.
\end{abstract}

Keywords: Interpersonal Dialogue, English Language Teaching, ability in using English

\title{
INTRODUCTION
}

English is the international language that is used as a unifying language of the world to communicate, including in Indonesia. Therefore, English is one of the subjects taught at all levels of education in Indonesia, including universities. Stated by Nation \& Newton (2008) that learning English adapts to the age, goals, background, and experiences of students in using English. English has 4 main skill; they are reading, writing, speaking, and listening, where speaking is an important element as part of life that should be developed to communicate (Derakhshan et al., 2016). Every skill uses a different learning strategy because it has a purpose that is not the same. Thus, the teaching strategy must be designed as much as possible in order to achieve the desired skill results (Anjaniputra, 2013). Then, the learning should be adapted to the needs of students, where the teacher as the implementer of learning must be able to modify learning and adapt to their actions in implementing learning (Nation \& Newton, 2008; Kyriacou, 2007). It

SPECTRAL Jurnal Ilmiah STBA Vol.6 No.2 Juni 2020 ISSN 0216-3381 


\section{Interpersonal}

Dialogue, ELT, Ability, Using English means that teachers have an important role to improve the student's ability to select and use the right strategy targets.

English for Office Communication (EFOC) is an English course in the STIE "Ind"

087 Pontianak curriculum. The main objective of this course is to develop students 'English language skills and increase students' confidence in using English. Based on observations, most of the students have weak English language ability. It is seen at the beginning of the meeting, the lecturer asked students to introduce themselves in front of the class using English, students are reluctant to appear in front of the class. This is because students lack the confidence to speak in English, even some students still want to speak in Indonesian. According to students, it is due to weak English language skills, students are not accustomed to speak the English language, minimal vocabulary, and students are not confident in using English. This is in accordance with the results Astuti (2019) research which shows that there are several factors that influence students to speak including vocabulary, pronunciation, grammar, self-confidence, anxiety, and mastery of topics. Furthermore, to train and build the confidence of students, lecturers apply interpersonal dialogue, where students build their own dialogue with fellow students. This study will describe the implementation of interpersonal dialogue in order to increase students' selfconfidence and ability in using English.

As the explanation above, it was found that the students have weak English language abilities, especially the ability to speak. There are two causes of students find it difficult to talk, are the lack of motivation in learning English and the lecturer uses inappropriate learning techniques (Akbar, 2018). Therefore, lecturers need to use an appropriate strategy, method, and learning technique to solve these problems. This is similar to that stated by Akbar (2018) The lecturer has the responsibility to have the right teaching method in order to solve the problems faced by students in learning English, which includes vocabulary weakness, shyness and lack of confidence in speaking English, feeling afraid to make mistakes, and so on.

Lecturers as implementing effective instructional strategies, when students are reluctant to speak, The lecturer must be able to encourage students to be actively involved in speaking English while learning is taking place to be able to communicate in class (Paul \& Hui-Ling, 2014). Broadly, it can be concluded that the lecturer has the main responsibility to implement the appropriate learning methods and strategies to solve the 
problems faced by students, especially in speaking English. In addition, lecturers are also expected to give the motivation to enhance the activity and participation of students in learning and speaking English.

As is well known, there are many learning strategies, methods and techniques that can be implemented in learning English, especially speaking learning. One of them is using dialogue. It is recommended to use the dialogue technique because it can improve and develop students' speaking skills (Akbar, 2018). Where the main component of this dialogue is the ability to determine the goals of the user in choosing the appropriate system, which is used as a medium to improve and sharpen students' analytical skills, and also as a tool for evaluating (Duran \& Battle, 2018; Gorsky et al., 2004).

There are two types of dialogue, are intrapersonal dialogue and interpersonal dialogue (Gorsky et al., 2004). Intrapersonal dialogue is defined as an internal process in which students build their own understanding, while interpersonal dialogue is a process that is related to the ability of how to enhance students' understanding. More deeply, intrapersonal dialogue is an interaction between students and learning material based on the learning resources provided, while interpersonal dialogue is an interaction between students and teachers or between students and students (Gorsky et al., 2007). According to Brown (cited in Derakhshan et al., 2016) There are several ways to develop students' speaking skills, including: "imitation, responsive, intensive, transactional dialogue, interpersonal dialogue, and extensive". It can be said that interpersonal dialogue is an effort to develop speaking skills.

There are several expressions used in interpersonal dialogue, namely: "greet and say goodbye; make introductions, identify yourself; extend, accept and decline invitations and offers; making and breaking off an engagement; expressing and acknowledging gratitude; praise and congratulate; react to the speech of the interlocutor; show concern, interest, surprise, sympathy, happiness, distrust, and disappointment (Celce-Murcia cited in Nuha, 2019). Based on these expressions, it can be said that interpersonal dialogue is a conversation whose content is more in the form of pleasantries that occur in social relationships. Based on the explanation described above, this study describes the process of implementing interpersonal dialogue in EFOC and what are the impacts of implementing interpersonal dialogue to build students' English language skills, especially speaking skills. 
Dialogue, ELT, Ability, Using English

089

\section{METHODS}

\section{Research design}

This study used a qualitative approach, with the aim of obtaining in-depth descriptive data that was in line with the objectives (Leavy, 2017). Where the purpose of qualitative research related to the evaluation, increase understanding, and give an idea (Raco, 2010). This study provides an explanation of the implementation of interpersonal dialogue in learning English, with the expectations of contributing knowledge in the form of exposure to the implementation of interpersonal dialogue in order to build students' confidence in using English.

\section{Data Collection}

The data collection was conducted in two phases, they are observation and interviews. The observations were made directly by the researcher, present in the classroom, to see the learning process by using interpersonal dialogue. Meanwhile, in the interview, the researcher conducted interviews with the lecturer which included the impact of implementing interpersonal dialogue on students. Interviews were also conducted with students to find out the impact of implementing interpersonal dialogue on their English language ability.

\section{Data analysis}

Once all the data is obtained, then the authors interpret all the data obtained, includes a summary of all findings, comparing the findings with the theory, draw conclusions, and propose limits and expectations of further research (Creswell \& Creswell, 2018).

\section{FINDINGS AND DISCUSSION}

\section{Findings}

1. Implementation of Interpersonal Dialogue

Based on the results of data collection using observation, it is found that the lecturer has a RPS or semester learning plan in one semester. The material in semester 1 is more on basic English, where the component teaches about grammar and dialogue. Lecturer at the first meeting at the beginning of each semester, ask students to introduce themselves in front of the class using English, in order to determine the basic ability of the students. 
Based on these results, Seen that the majority of English language ability is still weak and seen also they lack the confidence to speak the English.

Therefore, the lecturer designed a lesson with the aim of increasing student confidence in using English with the ultimate goal of increasing student ability. Then, the lecturer tries to implement interpersonal dialogue, with the aim of building a student's activity and effective communication between students and students, and students with lecturers. The specified theme adapts to the existing RPS. In this case, the topic of learning is "introducing oneself, making small talk, keeping conversation, and end conversation". Students are given the freedom to develop their own dialogue.

Lecturers carry out several stages, first, gives an example of a dialogue that corresponds to the topic; second, the teacher divides the students in pairs, where the distribution is done randomly; third, the lecturer instructs students to create, develop, and discuss dialogue scripts according to the theme; fourth, students perform in front of class; fifth, the teacher evaluates student performance, includes grammar for dialogue and corrects and gives examples of students' incorrect pronunciation, the lecturer explains it in front of the class and students pay attention to the explanation from the lecturer. This activity was carried out several times, considering total there are 15 pairs. This activity does take a lot of time, but given more direct knowledge about the destination to each student.

Of all activities, visible the activities of interpersonal dialogue, both between lecturer and students, as well as students and students. Due to the occurrence of communication in the form of a discussion about the theme being studied, began to write a script, solve the problems encountered, and during discussions. Lecturer instructs students to try to speak in English. Thus, the lecturer feels that by doing activities like this the entire range of skills and abilities in English can be fulfilled, especially improving the students' speaking skills.

2. The Impact of the Implementation of Interpersonal Dialogue

Interviews conducted for the lecturers, found that by applying an increase interpersonal dialogue of learning activities, where students become more active, and the establishment of interactive communications. By dividing students into a team, they indirectly have to discuss, so that this causes an increase in interaction between fellow 
Interpersonal

Dialogue, ELT, Ability, Using English

091 students. Then, there is also an increase in interaction and communication between lecturers and students. Because, according to the lecturer, with communication that is created, interpersonal skills are also awakened. Students are instructed to develop their own dialogue so that when they encounter a problem, they ask the lecturer directly. In this case, the lecturer has a full role as a facilitator. Furthermore, with the increased interaction between faculty and students, the students often inquire about the correct use of vocabulary, correct sentence structure, as well as the proper pronunciation. Because each student has his own problems, the evaluation system adopted by the lecturers are also more directly targeted to individual students and also increase knowledge for other students.

Interviews were also conducted with students, conducted on 15 teams, considering that each team had its own problems. From the interview results, most of the students thought that at the beginning of making dialogue, they are having difficulty creating a dialogue script and speak English due to their limited ability. However, because the learning process is discussion and open, they can inquire with other peers, as well as lecturers. Lecturers patiently guide during learning. Students also argue, with direct given such a task, learning becomes active, not boring as usual, where students just listen to any explanation from the lecturer. Then, because the lecturer gives instructions during the lesson they must use English, they can practice their ability to speak English.

Furthermore, students also argue, the implementation of learning becomes like "learning by doing". Then, in the process of making a dialogue script, students learn and find new vocabulary that they can find from a dictionary or translation application. They also get additional knowledge about sentence structure in correct English by asking fellow friends or lecturers. Not only that, they also feel that they are getting additional practice and additional speaking skills, be able to know the correct pronunciation of a word they initially thought difficult. Furthermore, by appearing in front of the class, discussing in English, and with all their limitations, students argue it adds to their confidence to speak in English. With the implement of interpersonal dialogue, students also felt the creation of communication and cooperation between fellow students. As well, students also feel completely involved during the learning process, coupled with support and guidance from the lecturer. 


\section{Discussions}

From the findings, it was explained that the lecturer had RPS regarding the lesson plans in one semester. It shows that the lecturer was ready with a set of lesson plans in implementing learning. With a learning plan, it helps lecturer to achieve learning goals, because it describes a series of activities that will be carried out by students and lecturers starting from the learning objectives, time, method, and so on. As stated by Nesari \& Heidari (2014) to assist lecturers in managing learning management, achieving learning goals, using various methods, and solving class problems, a lecturer must have a lesson plan. Lecturers choose interpersonal dialogue as a learning strategy to build interactive communication between lecturers and students, students and students. By building communication indirectly, both lecturers and students can develop interpersonal skills. It is described by Bhana (2014) There are several interpersonal skills that can be developed to create and build relationships, including communication, expression, listening, response, and so on.

Judging from the steps taken by the lecturer, it is almost the same as roleplay, because students have to appear in front of the class, playing the role of the dialogue script that they developed, and be evaluated. As the exposure and research from Dharmayanti (2013) regarding the effect of role play techniques on the development of students' interpersonal communication skills. The role play technique carried out includes appointing students to play the roles according to what has been determined, then after the students appear to have a discussion. The difference with that done by the lecturer and described in this study is that students are given the freedom to choose their partner, are given the freedom to develop their own dialogue script, and are given the freedom to play their respective roles. Then the discussion also began to build from the development of the dialogue, not only after students appeared in front of the class. It can be said, lecturers get students used to speaking English from the beginning to the end of learning activities.

Lecturer choose dialogue as a strategy to increase student participation with the main objective of increasing students' ability and confidence in using English, especially speaking. This was the right decision, as described by Janah et al (2016) dialogue provides advantages, including developing students' vocabulary, improving students' speaking skills, encouraging student confidence, and enabling students to master speaking in English. The lecturer instructs students to pair up and determine their own pair and 
Interpersonal

Dialogue, ELT, Ability, Using English

093 develop the dialogue according to a predetermined topic. It shows that the implementation of interpersonal dialogue has been carried out, because students are directly involved and have a dialogue with the people around them, in this case, their classmates, where the outcome orientation of the dialogue tang is made to refer to the learning material (Gorsky et al., 2007).

Interpersonal dialogue that can be seen during learning activities, especially during discussions where there is communication between lecturer and students, where the lecturer tries to help students when they have difficulty developing their dialogue. In this way, a lecturer seeks to enhance students' understanding of the structure of the English language the correct sentence. Where students gain additional knowledge, if communication is created between lecturers and students through dialogue, it is because the lecturer controls the implementation of learning (Abubakar, 2015).

Furthermore, interpersonal dialogue emphasizes the efforts made to increase understanding through interactions between lecturer and students, and students and students (Gorsky et al., 2004). Therefore, the implementation of learning must be able to provide opportunities for students to participate actively in order to gain new understanding (Bhana, 2014). Furthermore, with the creation of intense communication between lecturers and students, an effective learning process can also be created and can improve student academic achievement optimally (Dewi, 2016; Abubakar, 2015). Where effective teaching must be able to provide learning outcomes that must be achieved by students in accordance with the design desired by the lecturer (Kyriacou, 2007). Interpersonal dialogue is a complex heterogeneous type of conversation because it shows several functions that exist in conversation (Lastres-López, 2020). Thus, interpersonal dialogue provides a significant impact, not only perceived benefits for faculty and students, but for the learning process itself. Furthermore, with the development of interpersonal dialogue, it will result in the establishment of good relations between actors, such as sharing knowledge and information, and helping each other in solving a problem (Khodijah et al., 2018).

\section{CONCLUSION}

Interpersonal dialogue can be said as a way to create interactive communication between lecturers and students, as well as students and students. The emphasis here is to improve the ability to speak English, because by speaking, students will discover by 
themselves new vocabulary and correct English sentence structures. In principle, if the English language as a second language, to be able to master it often have to be trained and get used to using it. From the previous explanation, the lecturer implements interpersonal dialogue in order for the students to get used to using English and speaking English. Students feel the impact of implementing interpersonal dialogue such as learning becomes more fun, students become more active, acquire new knowledge such as vocabulary and grammar, and also self-confidence. Meanwhile, according to the lecturer, learning environment becomes more active and communicative, because students can fully participate in a series of learning activities. Furthermore, there is an increase in students' confidence in using English.

\section{REFERENCES}

Abubakar, F. (2015). Pengaruh Komunikasi Interpersonal antara Dosen dan Mahasiswa Terhadap Motivasi Belajar dan Prestasi Akademik Mahasiswa Effect of Interpersonal Communication Between Lecturer and Students of Learning and Achievement Motivation for Students. Jurnal Pekommas, 18(1), 53-62.

Akbar, A. P. (2018). The Implementation of Dialogue By The English Teacher In Teaching Speaking At The First Grade Students In MTS N Pare KEediri Academic Year 2017 / 2018. Simki-Pedagogia, 02(04), 1-8.

Anjaniputra, A. G. (2013). Teacher's Strategies in Teaching Speaking To Students At Secondary Level. Journal of English and Education, 1(2), 1-8.

Astuti, E. S. (2019). Faktor-faktor yang Mempengaruhi Speaking Performance Mahasiswa Jurusan Pendidikan Bahasa Inggris. Paradigma: Jurnal Filsafat, Sains, Teknologi, Dan Sosial Budaya, 25(2), 27-33. https://doi.org/10.33503/paradigma.v25i2.543

Bhana, V. M. (2014). Interpersonal skills development in Generation Y student nurses: A literature review. Nurse Education Today, 34(12), 1430-1434. https://doi.org/10.1016/j.nedt.2014.05.002

Creswell, J. W., \& Creswell, J. david. (2018). Research Design Qualitative, Quantitative, and Mixed Methods Approaches (Fifth Edit). Sage Publications, Inc.

Derakhshan, A., Khalili, A. N., \& Beheshti, F. (2016). Developing EFL Learner's Speaking Ability, Accuracy and Fluency. English Language and Literature Studies, 6(2), 177-186. https://doi.org/10.5539/ells.v6n2p177

Dewi, K. (2016). Pengaruh Komunikasi Interpersonal dan Pemberian Reward Terhadap Minat Belajar Melalui Motivasi Belajar Siswa Kelas VI Dalam Pembelajaran Bahasa Inggris di SD Kristen Petra 9 Surabaya. Petra Business \& Management Review, 2(1), $15-32$.

Dharmayanti, P. A. (2013). Teknik Role Playing Dalam Meningkatkan Keterampilan Komunikasi Interpersonal Siswa Smk. Jurnal Pendidikan Dan Pengajaran, 46(3), 256-265. https://ejournal.undiksha.ac.id/index.php/JPP/article/view/4228/3299

Duran, N., \& Battle, S. (2018). Conversation Analysis Structured Dialogue for MultiDomain Dialogue Management. The International Workshop on Dialogue, Explanation and Argumentation in Human-Agent Interaction (DEXAHAI), 
Interpersonal

Dialogue, ELT, Ability, Using English

095

December. https://sites.google.com/view/dexahai-18/home

Gorsky, P., Caspi, A., \& Smidt, S. (2007). Use of Instructional Dialogue by University Students in a Difficult Distance Education Physics Course Dialogue : A Theoretical Framework for Instructional Systems The framework rests on one assumption: Instruction = Dialogue ; three. Distance Education, 21(3), 1-22.

Gorsky, P., Caspi, A., \& Tuvi-Arad, I. (2004). Use of instructional dialogue by university students in a distance education chemistry course. The Journal of Distance Education, 19(1), 1-19. http://www.jofde.ca/index.php/jde/article/viewArticle/102

Janah, F., Sulistyaningsih, \& Prasetyo, Y. (2016). Teaching Speaking Using Dialogue For Describing Mother. Repository STKIP PGRI SIDOARJO, 1-11. http://repository.stkippgri-sidoarjo.ac.id/236/

Khodijah, S., . S., \& . T. (2018). Strategy for Increasing The Students' Interpersonal Communication Skills through Problem-Based Learning. International Journal of Educational Research Review, 3(4), 150-158. https://doi.org/10.24331/ijere.457979

Kyriacou, C. (2007). Essential teaching skills (Third Edit). Nelson Thornes. https://doi.org/10.1136/sbmj.0710361

Lastres-López, C. (2020). Beyond conditionality: On the pragmaticalization of interpersonal if-constructions in English conversation. Journal of Pragmatics, 157, 68-83. https://doi.org/10.1016/j.pragma.2019.12.011

Leavy, P. (2017). Research Design Quantitative, Qualitative, Mixed Methods, ArtsBased, and Community-Based Participatory Research Approaches. The Guilford Press.

Nation, P., \& Newton, J. (2008). Teaching ESL/EFL Listening and Speaking. In Teaching ESL/EFL Listening and Speaking. https://doi.org/10.4324/9780203891704

Nesari, A. J., \& Heidari, M. (2014). The Important Role of Lesson Plan on Educational Achievement of Iranian EFL Teachers' Attitudes. International Journal of Foreign Language Teaching \& Research, 3(5), 25-31. http://jfl.iaun.ac.ir/article_10884_43a5ff2bb7fbd6998f091eb726f80104.pdf

Nuha, U. (2019). Compatibility of Transactional and Interpersonal Conversation Texts in MTs English Textbook With The Standard of Content. Jurnal Penelitian, 13(1), 17. https://doi.org/10.21043/jp.v13i1.4836

Paul, C. T., \& Hui-Ling, T. (2014). Implicit and Explicit Teaching of English Speaking in the EFL Classroom. International Journal of Humanities and Social Science, 4(6), $38-46$.

Raco, J. . (2010). Metode penelitian kualitatif: jenis, karakteristik dan keunggulannya. Grasindo. https://doi.org/10.31219/osf.io/mfzuj 